December 2013. iAgent Rahela and I were cooking spiced potatoes for her family's breakfast over the fire pit behind her thatched house when her mobile phone rang. Something had happened near the railway station at the market town, a district official reported, and she should cancel her plans for the day and attend immediately. Rahela handed the wooden spoon to her younger sister and called iAgents Rimi and Brishti to join us. We wheeled our bicycles from her yard to the dirt road.

As the four of us cycled across the fields bordering the train tracks, we saw the upraised rail line, a throng of people, and train cars laying in unnatural positions. The train had derailed, and onlookers informed us that there were many casualties. The engine and the first few cars had shot off the tracks-at the location where the fishplates had been deliberately removed—and rested crumpled on their sides at the bottom of the steep embankment.

The time was one of unprecedented political chaos, at least in Rahela's memory. Opposition parties were boycotting the upcoming national elections because the ruling Awami League did not heed demands that it resign and establish a neutral administration to oversee the polls (M. Chowdhury 2015; Islam 2015). The protests (hartals) were forms of mass demonstration that meant the shutdown of workplaces, offices, shops, and roadways sometimes for a week at a time. Shutdowns were often enforced violently by sabotaging railway tracks, felling trees across highways, and throwing firebombs at vehicles daring to travel. Thus far, hartals for iAgents had meant that they needed to avoid markets, but the protesters primarily targeted shopkeepers and drivers who supported the ruling party, not girls on bicycles. Hartal violence had so far been a distant, nationwide reality, an ever-present danger. Yet this danger existed just beyond the boundaries of the "local," which for the iAgents and me meant the fifteen-kilometer (9.3-mile) radius within which we cycled each day. The national political drama had now entered the intimate and everyday lives of the iAgents.

We left our bicycles at Brishti's aunt's house in a village across the tracks and fought our way through the crowd. A family stood guard over a plot of young rice plants near the embankment and attempted in vain to hold back the multitude of onlookers and interrupted passengers with a length of rope. The train's engine car leaked thick black oil onto another family's tiny agricultural plot. A small boy, squatting in the field, used a piece of bent metal gathered from strewn train 
parts to spoon the oil into a plastic bottle. Hawkers availed of the concentration of people to sell newspaper-wrapped packets of puffed rice.

We searched for the officer who had telephoned Rahela. We found him in a dense cluster of people pointing their camera phones at the ground. The officer shuttled us to the center, where we encountered three dead bodies. "You have to take their photos so we can identify them," he instructed.

Rimi and Brishti pulled out their Sony cameras, and Rahela held out the tablet she had received as an award for high performance as an iAgent. At no point did the iAgents display emotion or self-consciousness as they shoved men aside to view the bodies and efficiently cover all angles. Rimi and Brishti commented jealously that Rahela had been the one called for the job because she possessed a tablet, which people considered a more professional piece of photography equipment than a point-and-shoot camera. Rahela retorted that they could have won the tablet too if they had decided to work harder. After promising to print copies of the photographs for the officer, the iAgents and I headed back to Brishti's aunt's house. We scrubbed the mud off our feet and trouser hems and then went to the nearby market to buy winter shawls.

The next day, people on the distant river islands where Rahela resumed her normal work discussed the train accident. Rahela interrupted these conversations by asserting that we had been there to witness it firsthand and she launched into a dynamic account of the event and the number of people who had died. Tears in her eyes, she described poignantly how seeing one of the three victims, an old man, made her experience intense suffering (onek kosto kortechi). She noted how dirty he looked lying on the hard ground, when he had probably bathed that morning in anticipation of the journey. He and the other victims did not have mobile phones with them, only small plastic bags carrying extra clothing and their tickets. "And they had only one more stop to go!" Rahela lamented, her tears streaming. She commented on the poverty of the three victims, which she interpreted from the quality of their clothing, and said that she had sobbed while looking at the old man. No one had come to claim them even twelve hours after the accident. "They didn't have anyone. Can you imagine how terrible it would be not to have any people?"

I wondered about the seeming disjuncture between Rahela's response at the accident site and her narration of it later. Perhaps she was initially in shock, and the emotion developed more fully in the social context of reliving and retelling. Perhaps also she intuitively knew that firsthand experience of local news was a resource that might connect her to her clients more personally. Perhaps her varying ways of dealing with the events were a means of coming to terms with the intense uncertainties and anxieties of life in rural Bangladesh as an iAgent.

In this book we see how young women occupy the forefront of transformation and ambitious expectation, as Bangladesh undergoes monumental change 
in its economy and society. They epitomize the liminality, precariousness, and ambiguity that characterize the country's experience with the conflicting registers of speculative growth accompanying developmental "success" and blockaded mobility generated by political chaos.

Two of "the world's busiest laboratories" (M. Chowdhury 2015, 192)—in constitutional democracy and market-driven development models—converge in this scene of young women attending to a sabotaged train in northwestern Bangladesh. The disruptive events and changes provoked by these "social laboratory" experiments in politics and development are summons for alternative and better futures, but they also intensify the already precarious existence of many people. In both cases-as the political elite engages in the destructive politics of violently contested elections and the economic elite marketizes social programs that previously existed as "charity" or "welfare" - it is the poor who are most negatively affected and who experience aggravated inequalities. Interrupted livelihoods, forfeited land, and the fear of not belonging to key social support structures are central to the stories of many families in Bangladesh. The train derailment not only symbolizes the unsettled everyday lives of citizens while political parties act at whatever cost to assert their agendas. It also serves as a metaphor for the ruptures that people face as new types of organizations rearrange social relationships in the name of poverty alleviation and societal betterment-for instance, as new patronage models threaten the ability of old patrons to look after their beneficiaries. Citizens experience these broader events as ethical disjunctures that reference the erosion of social values, which iAgents seek to repair for themselves through various projects.

Broader anxieties about the ways in which social relations are changing in Bangladesh are brought to bear especially on young women who challenge gender norms. This book documents the aspirations and struggles of young women who work as iAgent entrepreneurs as they try to handle the transitions from home-based work to outside work, from philanthropic modes of development organization to dispassionate market-driven ones, and from paternalistic patronage relations to detached ones promising “empowerment." This book traces changes within a social enterprise model in the context of emergent global development priorities, shifting class structures and relations, and gendered constraints and opportunities in the country. As Bangladesh further experiments with governance structures, liberalizes its economy, decentralizes its state functions, and submits its poverty-alleviation plans to local and global markets, young women - as garment workers, health-extension workers, microcredit customers, and iAgents-bear a remarkable burden of emergent and contradictory expectations and new forms of accumulation and aspiration. 



\section{TO BE AN ENTREPRENEUR}


